\title{
信息技术在小学语文教学中的运用
}

\author{
钟昕茯 \\ 江西省贑州市兴国县江背中心小学 \\ DOI:10.32629/jief.v2i10.2350
}

[摘 要] 随着时代的进步，信息技术的发展已经日趋成熟，信息技术在人们生活的各个领域都得到了广泛的应用，同时也取得了良好的应用 效果，为人类带来了诸多的便利。新课程改革下的小学语文同样也应当将信息技术充分地利用起来，以求在新时代的社会背景下培养出与社 会发展需求所对应的德智体美劳全方面综合素质发展的人才。本文就小学语文教学中信息技术的实践做出探究, 指出當代小学语文教学中信 息技术的应用现状，并提出若干建议，以望参考。

[关键词] 小学语文教学; 信息技术; 实践

中图分类号: G623 文献标识码: A

素质教育与新课程改革对教育领域提出的全新要求使得近些年小学 教学中广泛应用到了信息技术。在基础的学科小学语文中应用信息技术 能够帮助学生建立起浓厚的学习兴趣、充分掌握教材中的知识内容, 有 效提高学习积极性, 使小学语文的教学效率充分提升。虽然在近年小学 语文教学中对信息技术的重视程度有所提升, 但是在信息技术实际的应 用过程中还确实存在些许的问题, 因此通过科学的探究有效的将信息技 术的作用在小学语文教学中充分发挥出来是我们当先应当关注的重要课 题。

\section{1 借助信息技术，帮助学生识字、认字}

识字、认字，对于小学生而言，既容易犯错，也比较枯燥，特别是 对于低年级的小学生来说, 他们注意力不够集中, 很容易丧失学习兴趣。 如何有效地激发小学生对学习汉字的兴趣, 是一个值得深入思考的问题。 笔者认为, 教师可以通过信息技术和多媒体课件, 将识字的过程变得更 加有趣生动, 提高学生的学习兴趣, 增加课堂的吸引力。例如, 老师可 以将字的痕迹设计成各种有趣的形象和行为, 例如, 流星划过、蝴蝶飞 过的过程, 使用多种切换方式, 提高学生的注意力。此外, 借助于课件 可以对很多字进行更加形象的展示。例如在学习 “水” 这个字的时候, 教师可以在旁边加上水上波纹的动画, 是学生们形象地理解水字的由来。 在学习 “山” 这个字的时候, 可以加上多座山峰层叠的画面, 使学生们 对于山字的理解更加深刻。

\section{2 信息技术能够处理教学的重难点}

一般来说想象力为创新的基础, 教师要激励学生敢于去想, 引导学 生进行一些相关的想象。在语文教学环节, 多元化的网络资料与多媒体 课件的使用, 将情、光、景、声等融合在一起, 这样就会有较强的渗透 力, 可以有效的挖掘学生丰富的表象, 从而为学生给出宽阔的想象空间, 深化并激发了学生的想象能力。在教学的过程里, 因为受时间以及空间 的关系, 一些教学内容中存在的很多事物以及现象学生不能够很好的进 行理解, 而且, 就算是学生看到, 但是由于观察得不够深入也无法知道 一些现象的根源。多媒体能够将抽象的事物变成形象的, 将静态转换成 动态。教师若借助多媒体方式进行教学, 那么就可以将抽象的事物变得 直观、将静态转换成动态, 从而呈现形象的教学情境、将事物改变以及 发展每个细节进行深入的剖析, 且给出多元化的感知表象, 整合为一个 穿插式的 “思维体系”, 可以为学生由形象感知到抽象思维的转化创造途 径, 从而达到学生收益最大化的效果。

\section{3 提升小学语文课的活跃性}

结合小学语文课的授课经验, 要想让小学语文课具备更强的有效性 以及活跃性, 教师要将信息技术作为重要的辅助手段, 让小学语文课变 得更加具备活力, 学生在轻松的氛围下, 更容易保持大脑思维的兴奋程 度, 从而展开更加自主和充分地学习。学习氛围对学生的学习是有直接 影响的, 过去在小学语文课上学生感受更多的是沉闪, 但是教师若是可
以让小学语文课变得积极和活跃, 学生在小学语文课的学习就会更加投 入和积极。教师要结合小学语文课的授课需求, 在小学语文课上对一些 内容, 借助信息技术进行生动的展示, 从而让学生感受到小学语文课开 展的生动性以及活跃性, 让学生在小学语文课上的思维保持兴奋。

\section{4 通过多媒体让课堂氛围变得更加轻松愉悦}

为了进一步提升课堂教学质量, 则应该要求教师充分发挥好多媒体 信息技术教学的优势, 积极创设轻松的学习氛围, 保证学生具有较高的 学习效率, 这样能有效帮助学生放松心理压力, 能有效将自身更多的精 力放在学习知识的过程中。同时, 这种轻松的气氛有助于学生掌握相关 的必要知识, 培养良好的自主学习习惯, 加强自身的主观能动性的提升, 不仅能有效提升自身的语文学习成绩, 还能有助于全面提升新课标要求 下的素质能力培养的要求。

\section{5 注重教学方式的创新}

读写结合教学形式多种多样, 需要教师不断开阔视野, 树立大语文 教学观, 使信息技术的魅力得到淋漓尽致的彰显。如教师可以借助于学 校的云教育平台等形式, 成立微信读写群, 经常在群里发送一些适合学 生阅读的书籍, 学生登录学校的教育网络可以下载书籍, 并把自己的阅 读感悟和心得发送到群中, 其他学生也可以把自己的阅读感悟发出来, 大家一起品评、鉴赏, 共同提高, 共同促进。而学生也可以借助于学校 的教育平台把自己看过的有趣的书或者平时的生活感悟发出来, 教师看 到之后可以和学生交流沟通, 针对学生的语言文字进行积极评价, 提振 学生的写作自信。此外, 教师还可以成立家长微信群, 家长可以把孩子 每天的阅读情况发到群里, 把自己和孩子一起的亲子阅读视频或者孩子 写的生活感悟等文字发到群里, 这种方式既能激发家长们对孩子阅读能 力和写作能力的重视, 同时教师也可以对家长和孩子的互动情况进行分 析和引导, 借助于家长的力量, 使读写结合教学得到可持续发展。

社会和时代不断发展, 小学语文教学过程中, 应该积极借助信息技 术开展教学, 以此提高教学质量和效率。信息技术借助其自身的知识资 源的广泛性可以有效激发学生的学习质量和效率, 在实际的小学语文教 学过程中, 教师应该不断优化教学观念, 充分利用信息技术开展语文教 学, 并做好优化教学设计, 提高语文教学有效性; 同时创设良好的学习 氛围, 激发学生学习的兴趣, 不断提高教学质量和效率。

\section{[参考文献]}

[1]李意平.基于核心素养的小学语文群文阅读教学研究 [J].学周 刊,2019(09):123.

[2]钟福美.开展群文阅读培养核心素养 [J]. 当代教研论 丛,2018(04):44-45.

[3] 刘惠琼. 关于小学语文优秀传统文化教育的探讨 [J]. 学周 刊,2019(36):47. 